日心第74回大会（2010）

第2日 9月21日（火） $9: 30 \sim 11: 30$ A001

\title{
WS039 ものづくり心理学の実践
}

$\begin{array}{llll}\text { 企 画 者 } & \text { 金沢工業大学 } & \text { 神宮 英夫 } \\ \text { 司 会 者 } & \text { 金沢工業大学 } & \text { 近江 } & \text { 政雄 } \\ \text { 話題提供者 } & \text { 金沢工業大学 } & \text { 伊丸岡俊秀 } \\ \text { 話題提供者 } & \text { 金沢工業大学 } & \text { 田中 } & \text { 吉史 } \\ \text { 話題提供者 } & \text { 金沢工業大学 } & \text { 神宮 } & \text { 英夫 } \\ \text { 指定討論者 } & \text { 首都大学東京 } & \text { 笠松 } & \text { 慶子 } \\ \text { 指定討論者 } & \text { 味の素(侏) } & \text { 立山 和美 \# } \\ \text { 指定討論者 } & \text { カルピス(株) } & \text { 田手 } & \text { 早苗 \# }\end{array}$

\section{概 要}

心理学を応用したものづくりを目指す応用心理学として「ものづくり心理学」(engineering psychology) がある。2008 年は「五感の統合化とエモーションーものづくり心理学の可能性一」を、2009年は「ものづく り心理学の展開」を、W S として実施してきた。これは、「こころの働きを活かしたものづくり」を目指した もので、知情意の情意に着目して、新たなものづくりの可能性が期待できる。

本年は、産学連携の研究活動の成果を、実際の製品に関寸る研究から報告するとともに、企業のものづく りの第一線で活躍している研究者に、このようなものづくりの意味を企業側からの視点で議論してもらう。 新たな応用心理学としての可能性について、議論を進める予定である。 